\title{
INDONESIAN ISLAMIC MOVEMENT OF WOMEN: A Study of Fatayat Muslimat NU (1938-2013)
}

\author{
Hamidah \\ Fakultas Dakwah UIN Raden Fatah \\ Jl. Prof. K.H. Zainal Abidin Fikri KM. 3,5, Palembang, Sumatera Selatan, 30126 \\ e-mail: hmidah@ymail.com
}

\begin{abstract}
The purpose of this article is to examine the dynamics of Indonesian Muslim women's movement of a socio-historical study of the Moslem-Fatayat NU during the period 1938-2013. The socio-historical, Indonesian Islamic women's movement can exist not only from tahrirul mar'ah movement but also the influence of the feminist movement that developed in the Western world. The development of Moslem-Fatayat plays a strategic role in social transformation efforts. Transformation through a process of awareness that ran in "evolutionary manner" rather than radical which prescribes to actualization of classical islamic text book. The most rapid development Muslimat NU-Fatayat marked by: "return to khitah 1926" and Lombok General Assembly 1997 which let them out of practical politics. In addition, the development of Moslem organization backed by edict-Fatayat Lombok 1997, which resulted in the "position of women in Islam" or al-mar'ah fial-Islam that Islam recognizes equal rights between man and woman in the realm of religious order vance.
\end{abstract}

\begin{abstract}
Abstrak: Pergerakan Perempuan Islam Indonesia: Studi Tentang Fatayat Muslimat NU 1938-2013. Artikel ini bertujuan untuk meneliti dinamika pergerakan Muslimat-Fatayat NU selama periode 1938-2013 dilihat dari pendekatan sosial historis. Pergerakan perempuan Muslim Indonesia ada tidak hanya melalui pergerakan tahrîr al-mar'ah, tapi juga dampak dari perkembangan pergerakan perempuan Muslim di dunia Barat. Perkembangan Muslimat-Fatayat memegang peranan penting dalam upaya transformasi sosial. Transformasi dilakukan melalui proses kesadaran melalui "cara evolusi", bukan radikal yang mengharuskan aktualisasi buku-buku Islam klasik. Perkembangan paling pesat dari Muslimat NU-Fatayat ditandai oleh "kembali ke khitah 1926" dan Majelis Umum Lombok 1997 yang membawa mereka keluar dari praktik politik. Sebagai tambahan, perkembangan organisasi Muslim telah kembali dengan adanya dekrit-fatayat Lombok 1997, yang menghasilkan "posisi perempuan dalam Islam" atau al-mar'ah fi al-Islâm bahwa Islam mengakui hak antara laki-laki dan perempuan dalam bidang agama sama.
\end{abstract}

Keywords: Indonesia, perempuan Muslim, NU, Fatayat Muslimat NU 


\section{Introduction}

Tracing the history of Indonesian Muslim women's movement, its existence can not be separated with mar'ah al-Tahrir movement that flourished in Islamic countries and feminism that developed in the Western world. All three are in the chain. It may be the emergence of Islamic women's movement was the influence of the feminist movement in the West, although this did not deny the existence of the internal dynamics of Muslim women themselves.

Feminist movement in the West, according to Syafiq Hasyim, walking with a hook intertwined with movements in Islamic countries, within the meaning of feminism in the West has influenced the emergence of feminism in the Muslim world. The nature of the egalitarian feminism movement, to make this movement dealing with religious character of patriarchy, mode of patriarchal religion means that no essential nature of true religion, but of a social structure and cultural formations of patriarchy. ${ }^{1}$

In the early 19th century AD, Middle East society began to consider social change fundamentally. Dredging wealth by Western countries, the emergence of nation-states, and colonization of both formally and informally by the colonial powers in the late 19th and early 20th century have formed the parameters of economic and political changes that are very important. This is not just happening in Arab Islamic countries, but also Muslim countries including Indonesia, non-Arab countries such as Indonesia which is bias affected.

Feudalism ${ }^{2}$ has changed them, from the figures that have great social responsibility to citizens who are treated as something that is respected and revered. Awareness of responsibilities women have in the past that is quickly becoming increasingly weakened, even in some places eventually lost. At the time of colonialism in general position of women in all positions is decreased.

However, at that time also many good and brilliant mind that voiced by some Indonesian women, the pioneer of Indonesian women's emancipation. Harsja W. Bachtiar classified these women figures into two groups, namely: First, the women who attract the attention of the Dutch in the colony, because they perform activities that should be appreciated and commended. They consist of figures like R.A. Among the Javanese Kartini, Dewi Sartika among the Sundanese and Maria Walanda among the Minahasa. They are considered give appreciations because the ideas and their activities in harmony with the Dutch business in the late nineteenth century and early twentieth century; Second, the women who attract attention precisely because they are against the Dutch, against the Netherlands, consisting of such figures as Cut Nyak Din and Cut Meutia in Aceh, RA Nyai Ageng Serang. Attack in Central Java and Martha Christina Tiahahu in Maluku, female characters who eventually

${ }^{1}$ Syafiq Hasyim et.al, "Gerakan Perempuan dalam Islam Perspektif Kesejarahan Kontemporer," in Tashwirul Afkar, No. 5, 1999, p. 3-4.

${ }^{2} \mathrm{Feudalism}$ is a social or political system that gives enormous power to the aristocratic class. Drafting Team, Kamus Besar Bahasa Indonesia (Jakarta: Balai Pustaka, 1997), p. 275. 
killed, banished to another area or put to death. They are regarded as rebels who attract attention because it deviated from habit, opponents of the Netherlands is not male but female. ${ }^{3}$

Initial thoughts of these women is a starting point for the formation of Indonesian women's organizations. Cora Vreede-De Steurs mention, the first Indonesian women's organizations are Princess Mardika founded in 1912, with the help of Budi Utomo. The organization provides scholarships to girls to continue their studies. The emphasis is that to be financially independent. ${ }^{4}$ Many religious organizations to form women's sections, such as Aisyiyah part of Muhammadiyah; Nahdlatul Fatayat (now known as MuslimatNU), a part of member at NU, and Wanodya Utomo, part of SI.

This article is focused on the dynamics of Indonesian Muslim Women's Movement, one of which was pioneered by the birth of the Moslem-Fatayat, NU women in socio-historical context of the period 1938-2013. The formulation of the research question: "How do the dynamics of the Indonesian Islamic women's movement of a socio-historical study of the Moslem-Fatayat NU during the period 1938-2013?

\section{Research Methods}

This research shaped qualitative phenomenological study with the type of descriptiveanalytical study of Indonesian Islamic women's movement: a socio-historical study of the Moslem-Fatayat (1938-2013). According to G. Convelo Seville: "descriptive method aims to describe the nature of a situation that while walking on the time of the study and examine the causes of a particular symptom."

Sources of data are acquired in the form of qualitative data and quantitative data. The qualitative data is acquired from a variety of reading materials which are from the library in the form of primary data and secondary data. The primary data in the form of literature written by people directly involved in the organization, other than that in the form of the decision of the congress, conferences and so forth. The secondary data in the form of literature written by analysts and scientists both directly and indirectly interested in reviewing matters of women's organizations in general, that is written in the form of books, articles in scientific journals, newspapers, seminar papers and so forth. Quantitative data is being acquired directly from the relevant member of the central organization.

In addition in collecting written data, data collection can be acquired from the process of observation and in-dept interview. Observation was done because there are certain types

${ }^{3}$ Harsja W. Bachtiar, "Kartini dan Peranan Wanita dalam Masyarakat Kita," in Satu Abad Kartini 1879-1897 (Jakarta: Sinar Harapan, t.t.), p. 80-81.

${ }^{4}$ Cora Vreede-De Steurs, The Indonesian Woman, Struggles and Achievements (Gravenhage: Mouton and Co., 1960), p. 61.

${ }^{5}$ Convelo G. Sevilla, et al., Pengantar Metode Penelitian, translated by Alimuddin Tuwu (Jakarta: UI Press, 1993), p. 71. 
of data that can not be reached by the interview data collection techniques. For completeness of indirect observations conducted by researchers, used the method in-dept interview. This technique is used to understand the construction of subjectivity informant about Indonesian Islamic women's movement.

After going through the selection stage, data is then analyzed by using the socio-historical approach, the method of content analysis, and critical analysis. First, the socio-historical approach is a combination of sociological and historical approach. Sociology is a science describes the state of society complete with structure; layers and various other social phenomena are interrelated. ${ }^{6}$ whereas according to Gilbert's historical approach is a set of rules and principles systematically to collect historical sources effectively, critically evaluate, and propose a synthesis of the results achieved in written form. ${ }^{7}$ This method is used mainly in track and assess the background incidence of the Organization-Fatayat Moslem women in socio-cultural context of Islamic society at the time and saw further development, the position and status within a particular organization within the context of government policies of the ruling. Second, content analysis (content analysis) by Barcus is a scientific analysis of the contents of the message of a communication." ${ }^{8}$ Content analysis method used in this study to explore the various ideas associated with the congresses and conferences, the Articles of Association Bylaws (AD/ART) underbow NU women's organization is even the result of the interview will also be analyzed. Third, a critical analysis of one blade analysis using the theories contained in the sociology of science, particularly relating to the structure and form of organization. In addition, theories relating to the history, internal criticism and external criticism and so forth that are used in tracing the background of the formation-Fatayat Moslem organization in the socio-historical context. Similarly, the theory of developed in studies of femininity both in the context of feminism in the West or tahrirul mar'ah that flourished in the Islamic world, which both either directly or indirectly have a significant relationship.

\section{Findings and Discussion}

The organization's first woman in NU known as Muslimat NU. At the first, the establishment does not accept Muslimat NU as a member, but consisted only of the Muslims and the scholars only. Because at that time scholars have thought that it is not time Muslimat opted to move in the union or organization. Women should take care of household only. They were not allowed out of their own and do not have any desire to move outside the home. Things like this run for several years until in 1938 that the NU congress to XIII in the Menes.

${ }^{6}$ See Abuddin Nata, Metodologi Studi Islam (Jakarta: Rajawali Press, 1998), p. 39.

${ }^{7}$ Gilbert J Garraghan, A Guide to Historical Method (New York: Fordham University Press, 1957), p. 33.

${ }^{8}$ Noeng Muhadjir, Metodologi Penelitian Kualitatif (Yogyakarta: Rake Sarasih, 1989), p. 76. 
In addition Muslimat NU, women's organizations underbow NU is Fatayat NU which is an organization that girls (young women) of Islam and one of NU autonomy founded 7 Rajab 1369/24 April 1950. Pro and contra of establishing this organization is too sharp, because the majority of scholars do not want to exist. Underbow NU women's organizations are organizations that are categorized as old and still survive to present. This organization has members who are big enough not only in Indonesia but also in Asia. Greatness of this organization is not only quantitative but also in the perspective of the qualitative perspective. The role and influence of women's organizations are large enough to the dynamics of growth and development of Indonesian society.

\section{Socio-Historical Muslimat NU}

Starting from 1938 Muslimat NU has been accepted as a member of the NU, although membership is just a follower and listener only, not allowed to occupy the management seat. This is enough to motivate of the Moslem at that time.

In the Encyclopedia of Islam explained that NU was born on the 15th NU congress in Surabaya (15 to 21 June 1940) under the name NU Muslimat (NUM). At that time the organization is still a part of the NU, not to stand on its own. ${ }^{9}$

At the XVI congress of NU in Purwokerto in 1946, the planning makes the Moslem would be a part of the NU brought forward to the congress. As a result the delegates unanimously approved the NU congress and decided: “...To accept the proposal to make the Moslem as part of NU which is then validated and formalized in a plenary meeting on 26 Rabi 'Late 1335 or March 29, 1946, an organization with the abbreviated NU NUM ..."10

Discussing the dynamics of Muslimat NU, the role of NU women who had been struggling to become an organization that counts and has a huge contribution to the Indonesian Islamic women as described in "Women in Development" (WDP ", especially during the first decade of the last of the year 1976-1985. Women and Development which is in English Gender and Development (GAD), as described by Muhadjir, focusing the movement on gender relations as the reality of development. The movement was popular in the 1980s was based on the assumption that the basic problems in development is the existence of an unfair gender relations. The situation is the challenge in equitable development and full participation of women. In this context, gender issues must be put forward to combat the sources of injustice. ${ }^{11}$

${ }^{9}$ Dewan Redaksi Ensiklopedi Islam, Ensiklopedi Islam (Jakarta: Ichtiar Baru Van Hoeve, 1993), p. 348.

${ }^{10}$ Ny. H. Syaifuddin Zuhri, et al., Sejarah Muslimat NU (Jakarta: PP Muslimat NU, 1979), p. 56.

${ }^{11}$ Muhadjir, Negara dan Perempuan: Reorientasi Kebijakan Publik (Yogyakarta: Media Wacana, 2005), p. 29. 
WDP concept is often criticized the strategy and its work more focused on women and how to integrate the role of women in all areas of development, without giving a clear definition of the role itself. Therefore, what happens then is that women increasingly heavy burden because they have to contribute as much as possible and as wide as possible, both in family and society. By applying the concept of WDP attention also directed to women only and not seeing the links between the roles of WDP, also questioned the lack of social structure which is the source of discrimination against women and why they have less benefit from the development process. WDP does not have a sharp analysis.

Moslem women leaders feel that the Moslem women have been left, particularly in education. They motivated to fight increasing welfare, education, dignity and advancement of women in various fields. They finding practical away but effective, although it may take a long time, and did not travel with the discourse strategy of suing the role of women in full of critic, "fierce" and confrontational. They chose to do something directly felt by broad layers at the grassroots level. They train becoming for the development of communities in various places throughout Indonesia. Indeed awareness of women's backwardness among NU has emerged since 1938 when NU Congress ${ }^{12}$ in Menes.

There may be an opinion that NU is less dynamic, less radical, less vocal and so forth. Apart from the assessment based on existing records through the 26,000 branches (subdistrict level / village) has given a great contribution to the life of nation and state, in social life, education, health, economic and political. According to the records is also up to now only six people who had become general chairman of NU PP, namely Chodijah Dahlan (19461947); Hindun (1947-1950); Machmudah (1950-1979), Asma Sjachruni (1979-1995); Aisyah Hamid Baedlowi (1995-2000); Dra. Khofifah Indar Tarawangsa (2000-2005); Dra. Khofifah Indar Tarawangsa; and Dra. Khofifah Indar Tarawangsa (2005-2010).

\section{Socio-Historical Fatayat NU}

Revealing the dynamics of a women's movement is an attempt to explore the journey of its history, it is a reflection of a form of social system and the struggle of ideology, politics and policy of the authorities of one period of power to other power period. Searching for the NU women's role, including Fatayat in it, is an effort to discover what is behind the majority of Moslem women in Indonesia.

The socio-historical, Neng Darah Affiah has mapped the NU women's wrestling (Fatayat) in three stages. First, the pioneering phase (1950-1953). This stage starts from Surabaya, East Java and surrounding areas by several women who became known as "the

${ }^{12}$ At these conferences Hj. R. Djuaesih spoke with passion. She said, "In the religion of Islam, not only men who should be educated about religious knowledge and other knowledge. The Moslem Women was obliged to get an education that is consistent with the will and demands of religion. Therefore, the Moslem Women who joined member of NU must be rise." 
Three" founder Fatayat. At this time the deployed force and the pioneering mind is incredible. They had to struggle to convince its parent organization, the NU about the need to establish a container of women in this organization. They do lobby to the high leaders' NU and charismatic Kyai more often. They have to face the challenges that can weaken their morale.

There are several obstacles faced in establishing Fatayat, whether they are structurally associated with the leaders of NU and cultural nature, namely a patriarchal culture and hegemony limited access for young women in their family. In detail the obstacles and barriers, among others: (1). Not supported by Syuriyah NU. At the time of "the Three" read the ideas and desires regarding the establishment of Fatayat at NU Congress in Jakarta in 1950, the response of elderly Kyai NU especially Rois Syuriyah KH Bisri Sansuri, it is not fun. "... Not use Fatayat-fatayatan ..."," ... if we want to create just join an organization with Muslimat ...", “... our principal from the chaplain does not allow and do not believe ... later on it could be like a horse “. Indeed, KH. Bisri Sansuri who is known by many people is a very strange figure, stiff and no compromise. Although supported by KH Dahlan, but the conflict that occurred between the kyai on the establishment Fatayat is very debatable. The debate has a very strong historical foundation when we look at how the social setting and position of women in the discourse of male relations (2). The tradition of patriarchy and patronage. The tradition of patriarchy and patronage of clerics is not favorable to the originator of this NU Fatayat organization early. The strong male dominance, both in domestic and public spaces has actually been castrated motion activity cadres NU young daughter and the campaign is to spread ideas and their ideas. Even to hold an event agenda, they also must receive prior approval from the religious scholars and administrators of NU. These conditions certainly their creativity to take the role of developing NU, especially the young daughter (3). Weak human resources young women NU. In the past, the average woman at a young age has got married or even already have children. Parents do not consider education important for women. The view that developed at that time was the daughter does not need a high education, because parents worried about the hard to find a man. If you are married, they are the responsibility of her husband. In the context of such a narrow space and a hostile social system, efforts to mobilize the power is very difficult for the founding mother, not to mention when dealing with clerics who thought still conservative. ${ }^{13}$

The process that they began in 1950 recently was legalized by NU as an organization of autonomous body in 1952. The effort Fatayat to achieve its goals: (1) raise and nurture young Muslim girls or women in the organization Fatayat NU, (2) improve the quality of education, instruction, skills, and expand knowledge for the benefit of religion, nation and state, (3) increase the role of Indonesian women in all spheres of life, religion, state and society, (4) enhance the mind (al-karimah morality) in daily life, (5) carries on business and has

\footnotetext{
${ }^{13}$ Neng Dara Affiah, Menapak Jejak Fatayat NU: Sejarah Gerakan Pengalaman dan Pemikiran (Jakarta: PP Fatayat NU, 2005), p. 11-12.
} 
worked to support religious syiar; (6) develop friendships with other organizations, especially youth and women organizations.

In those years, they formed a community organization that is began by recruiting members from the people closest to and around the territory which later became the embryo formation of branches, twigs and regions. They also create a program to fund an organization that truly self-supporting ${ }^{14}$ without the help of others. Important contribution to Fatayat NU called at this period is that its presence "enlightening" women who from the bottom are santri. Priority program to establish educational institutions, ranging from education levels kindergarten (kindergarten) to school teachers. They also performed the eradication of illiteracy ${ }^{15}$ (because at NU this time many women who can only read the Arabic alphabet, but can not using Latin script), conducted the course skills such as sewing, embroidery, embroidery, cooking and others. In addition, conducting courses, such as English classes. Even, in the face of the revolution, they had military training: shooting, using grenades, and so forth.

The second phase is the period of development and consolidation of the organization (1953-1969). . ${ }^{16}$ Outside of Fatayat organization, government climate also provides space motion is quite positive toward women. A number of witnesses of history states that during the reign of Sukarno and more women who control key positions in government and have the intellectual acuity. Something similar happened also in the NU environment. ${ }^{17}$

From the results of exploratory Neng Darah Affiah obtained during this period that women get a pretty respectable space in the world of justice. NU is one of the organizations that have progressive religious views that allow women to be judges of religion, a view which is advanced in the Islamic world because it has changed the way most people think of distrust that has been legitimized by religious interpretations of women's testimony. In 1953 Syria

\footnotetext{
${ }^{14}$ Being members of $\mathrm{NU}$ can be seen to have a broad dimension. In addition to its Javanese culture that makes them tied with the feel of "feudalism" kejawaan namely adherence to the one who is believed to be a representation of faith, they also feel that what they are doing is the essence of worship. Therefore, the cost, effort, time and thought is not something that's useless but it would be but an implementation of worship. See H.M. Ridwan Lubis, "Dynamics of the Under MuktamarNU," daily newspaper Alert, Medan, 1 January 2005, p. 4.

${ }^{15}$ In 2006 literacy programs into one program of national education ministers (minister) to involve all women's organizations and then followed up with the technical implementation in the regions with data collection prospective citizens learn (WB) and the preparation of curricula.

${ }^{16}$ In this period the organization has begun to form Fatayat in almost all of Indonesia, such as Kalimantan, Sulawesi and Sumatra from the area until the twig. In addition to continuing existing programs, strengthen its program with NU Fatayat Indonesian course, because at that time Fatayat NU members from various regions and branches usually only communicate with local language, but not usually communicate with their national language.

${ }^{17}$ In Syuriah NU congress in 1957 stipulated that there should be representation of women in the legislature. So at this time a number of women from the political party NU. NU was a member of the legislative representatives from various regions. Long before the discourse of $30 \%$ of the women in the legislature in effect, $\mathrm{NU}$ has started thanks to representatives in the legislature.
} 
NU set a policy that allowed women to enter the Faculty of Shariah, and as a consequence of the policy, women are allowed to become a judge of religion, a position which until now in some Islamic countries are not allowed to judge religions, such as Malaysia and Saudi Arabia. The policy emerged when KH. Wahid Hasyim served as Minister of Religious Affairs (1953).

Besides the legislature, many women in the reign of President Sukarno became the leader at the local level, as chairman of Neighborhood (RT), Pillars of Citizens (RW), and village heads. So in 1962, NU congress in Salatiga, issued a fatwa that women NU, allowed to become head of the village. ${ }^{18}$

Changes in government policy directly or indirectly might influence the development and dynamics of organizations including women's organizations in the NU. Under the leadership of Soeharto, NU organizations and autonomous agencies, including underbow Fatayat NU in it controlled its movement so that these organizations have limitation in action.

The result of interview data gathering team writing a book Menapak Jejak Fatayat NU; Sejarah, Gerakan, Pengamalan dan Pemikiran by Aisyah Hamid Baidhowi, that some regional managers often reject the arrival of the central committee and Muslimat NU PP Fatayat, because they were afraid government would know it.. Asthma Syahruni and H.S.A. Wahid Hasyim, for example, have experienced rejection of the former chairman of the Muslimat NU Ponorogo, because there are children who became headman. Instead of endangering her son that the old man, he sent a letter which read: "I still love Muslimat, but do not come to my house." Because the situation is so pressing, many members of NU at the time who chose to compromise, such as joining Golkar Party Government. At this time, for about twelve years old, both Fatayat NU and other Islamic organizations almost are said they were doing nothing... Nevertheless, managers still exist, but its activity is not running. General Chairman of Fatayat NU at that time was Malichah Agus. ${ }^{19}$

Third Stage, Awakening Back Fatayat NU (1979-1994). After almost twelve years has no significant activity, in 1979, and Fatayat Muslimat NU held a congress in Semarang. It was elected general chairman Mahfudhoh Ali Ubaid. She was together with other administrators began to revive the existing cultural organizations with re-start consolidation of organizations in different regions and branches throughout Indonesia. Consolidation was originally done in prone and by stealth, but when Fatayat start the program in line with government programs, the Family Planning (FP), consolidation can be done more freely.

NU Fatayat in those days had compromise with government policy. If not, Fatayat would get destruction as occurred in other organizations when it conflicts with government policy. New Order government through organizations such as Darma Wanita, Dharma Pertiwi

\footnotetext{
${ }^{18}$ Affiah, Menapak Jejak Fatayat NU, p. Xx.

${ }^{19} I b i d .$, h. xx.
} 
and $\mathrm{PKK}^{20}$ promote family planning program, the skills were around the house and Mother and Child health. Fatayat organizations also endorsed them with a similar program. Mahfudhoh Ubaid Ali, Chairman of the PP Fatayat NU (1979-1989) argued that government programs that followed Fatayat is integrated health, organic pharmacy, a wholly dasawisma which were included in the Family Welfare Education Program (PKK). ${ }^{21}$

From interviews with the author's Aisyah Baedlowi about the dynamics of the NU women's organizations that: in the 80's, both Fatayat NU and Muslimat NU became acquainted with international organizations like UNICEF, ADB, and others. Despite initial cooperation with foreign organizations provide funding to obtain the refusal of some Jam'iyah NU because they work together with the "infidels." 22

When the feminist movement ${ }^{23}$ began exist in Indonesia, a little more movement will affect the Indonesian women's organizations including the Moslem and Fatayat NU. Fatayat NU in 1990s to adopt that perspective to conduct gender analysis exercises. Mainly For the main Fatayat NU use of gender analysis as a knife diff to see the religious texts of Islam, especially the Qur'an, the Hadith and the literature of Islamic law with a new paradigm, especially for those that were associated with the pattern of relationships between men and women. A number of sensitive issues related to sexuality issues previously considered taboo talk about, starting dismantled with meaning and a broader understanding. Raised the issue of sexuality is not merely an individual problem, but it had wider social implications. Female domestic problems closely related to issues in the public world, so when Fatayat reveal problems of polygamy, female circumcision, abortion, the right to determine the couple lives, and others was not merely the issue of the issue, far more important was the effort to capture a monopoly of religious interpretation and political rights of women with a broad meaning and scope.

Originally the concept of gender had a very strong rejection of most of the clerics.

\footnotetext{
${ }^{20}$ At first Fatayat and Muslimat NU prohibit allied with organizations that formed the New Order government. This is because in 1984, through Congress in Situbondo, NU Khittah set himself back on 1926 as an organization-oriented human resource development through religious social movements. Cooperation with existing cultural and Moslem organizations formed the New Order government was feared would reduce NU neutrality in politics and is affiliated to a political party in power at that time, namely Golkar.

${ }^{21}$ Affiah, Menapak Jejak Fatayat NU, h. xxi.

${ }^{22}$ Wawancara dengan Aisyah Hamid Baedlowi, Jakarta Desember 2005.

${ }^{23}$ Women's movement that a gender perspective, a perspective that unpack (deconstruction) long understanding of gender roles in at least three things. First, the dismantling of the meaning of "nature" or something that is considered natural for women. Second, dismantle the old understanding of the sexual division of labor argument. Third, this perspective opens the space to trace the roots of the social history of why it appears subordination, marginalization, violence and injustice tehadap women while recognizing the power of self-organizing collective strength. In addition, this approach also promote participatory development programs for both gender with its emphasis on the empowermentapproach.
} 
This refusal was based on at least three arguments: First, the concept of gender was a foreign concept (west), not necessarily in accordance with gender relations in Indonesian society, particularly Islam. Second, the concept was feared to undermine the teachings of Islam, especially Muslims who understood among nahdhiyin. Third, there was a lack of some of them with the changing patterns of relationship of husband and wife in the household.

But this rejection successfully pushed over by a number of intellectuals and scholars who have thought NU progressive and open to change. A number of names that can be mentioned here is Masdar F. Mas'udi, KH. Husein Muhammad, KH. Agil Siraj and some support for a number of NU women who fought to uphold justice among men and women.

Another name which is no less important has a major contribution to the dissemination of ideas of gender justice is a KH Abdurrahman Wahid. At the thought of equality and gender justice is rolled out in Fatayat NU, at that time he served as General Chairman Tanfidziah NU. KH. Abdurrahman Wahid was the one who allows the opening of the organization NU on the ideas of change. He was also an open faucet emergence of Islamic thought cosmopolitan insight-oriented: oriented towards gender equality, openness to other religions has the insight of universal values, striving to uphold a democratic country with the principle of upholding the values of Human Rights.

Since then the ideas of gender equality began to be implemented, not just limited to the discourse but also implemented in the form of concrete actions to conduct advocacy at the policy level, engage in lower level people awareness and build the institutions ${ }^{24}$ that try to provide solutions to problem- concrete problems faced by society, such as domestic violence and issues related to women's health.

Short in the important contribution of the most significant Fatayat NU is to educate the women of the culture of santri how they must be a "human being" with the choices they want. Although they had to deal with religious understanding which is thick with the systems that marginalize women.

The whole process since its establishment until now has undergone many changes, such things happen because Fatayat open to change, it absorbs, reflect, strategize and initiate action. Thing has not changed from those is in conducting a strategy to exist become an important part of Indonesian Muslim women's movement that has undergone many developments and strategic role in the period 1938-2013. Underbow NU women's organizations is a picture of Indonesian Islamic feminist movement in which there is an intensive dialogue on justice and gender equality contained in the text with the reality that occurred in Indonesia's Islamic community.

${ }^{24}$ Now Fatayat NU has 26 units in 26 districts Institute for Women's Empowerment Consultation (LKP2) and the Center for Reproductive Health Information (think the) in various parts of Indonesia. 


\section{Conclusion}

Referring to the focal point of the dynamics of Indonesian Muslim women's movement of a socio-historical study of the Moslem-Fatayat NU during the period 1938-2013, it can be concluded as follows: First, the Indonesian Muslim women's movement can not exist apart from the movement that mar'ah tahrirul develop in other Muslim world which is also the influence of the feminist movement that developed in the Western world. Second, The socio-historical, development-Fatayat Muslimat during the decade 1917-1998 as the women's organization underbow NU plays a strategic role in social transformation efforts, including the interpretation of religious teachings are gender sensitive.

\section{References}

Affiah, Neng Dara (ed.). Menapak Jejak Fatayat NU: Sejarah Gerakan, Pengalaman dan Pemikiran. Jakarta: PP Fatayat, 2005.

Aisyah Hamid Baidlowi. "Profil Organisasi Wanita Islam: Studi Kasus Muslimat NU," dalam Lies Marcoes-Natsir dan Johan Hendrik Meuleman (ed.). Wanita Islam Indonesia dalam Kajian Tekstual dan Kontekstual. Jakarta: INIS, 1993.

Bachtiar, Harsja W. Kartini dan Peranan Wanita dalam Masyarakat Kita, dalam Satu Abad Kartini. Jakarta: Sinar Harapan, t.t.

Baidlowi, Aisyah Hamid, et al. 50 Tahun Muslimat NU Berkhidmat untuk Agama \& Bangsa. Jakarta: t.p., 1996.

Bruinessen, Martin van. "NU: Jamaah Konservatif yang Melahirkan Gerakan Progresif," dalam Laode Ida. NU Muda Kaum Progresif dan Sekularisme Baru. Jakarta: Erlangga, 2004.

Bush, Robin. "Wacana Perempuan di Lingkungan NU Sebuah Perdebatan Mencari Bentuk," dalam Tashwirul Afkar, Edition 5, 1999.

Darwin, Muhadjir M. Negara dan Perempuan Reorientasi Kebijakan Publik. Yogyakarta: Media Wacana, 2005.

Dewan Redaksi Ensiklopedi Islam. Ensiklopedi Islam. Jakarta: Ichtiar Baru Van Hoeve, 1993.

Hasyim, Syafiq, et al. "Gerakan Perempuan dalam Islam Perspektif Kesejarahan Kontemporer," in Tashwirul Afkar.

Interview with Aisyah Hamid Baedlowi, Jakarta Desember 2005.

Lubis, M. Ridwan "Dinamika di Balik Muktamar NU," in Waspada, Medan, 1 Januari 2005.

Ma'sum, Saifullah (ed.). 50 Tahun Muslimat NU Berkhidmat untuk Agama dan Bangsa. Jakarta:Pucuk Pimpinan Muslimat Nahdlatul Ulama, 1996.

Muhadjir, Noeng. Metodologi Penelitian Kualitatif. Yogyakarta: Rake Sarasih, 1989.

Mulia, Musdah. "Perempuan Pembaru Keagamaan dari Fatayat NU," dalam Neng Darah Affiah (ed.), Menapak Jejak Fatayat NU: Sejarah Gerakan, Pengalaman dan Pemikiran. Jakarta: PP Fatayat NU, 2005. 
MIQOT Vol. XL No. 1 Januari-Juni 2016

Nata, Abuddin. Metodologi Studi Islam. Jakarta: Rajawali Press, 1998.

Sevilla, Convelo G. et al. Pengantar Metode Penelitian, translated by Alimuddin Tuwu. Jakarta: UI Press, 1993.

Vreede-De Steurs, Cora. The Indonesian Woman: Struggles and Achievements. Gravenhage: Mouton and Co., 1960.

Zuhri, Syaifuddin, et al. Sejarah Muslimat NU. Jakarta: PP Muslimat NU, 1979. 